\title{
Effects of land use/land cover and climate changes on surface runoff in a semi-humid and semi-arid transition zone in northwest China
}

\author{
Jing Yin ${ }^{1}$, Fan $\mathrm{He}^{1}$, Yu Jiu Xiong ${ }^{2,3}$, and Guo Yu Qiu ${ }^{4}$ \\ ${ }^{1}$ State Key Laboratory of Simulation and Regulation of Water Cycle in River Basin, China Institute of Water Resources and \\ Hydropower Research, Beijing 100038, China \\ ${ }^{2}$ Department of Water Resource and Environments, School of Geography and Planning, Sun Yat-Sen University, \\ Guangzhou 510275, China \\ ${ }^{3}$ Department of Land, Air and Water Resources, University of California at Davis, Davis, CA 95618, USA \\ ${ }^{4}$ Shenzhen Engineering Laboratory for Water Desalinization with Renewable Energy, School of Environment and Energy, \\ Peking University, Shenzhen 518055, China
}

Correspondence to: Yu Jiu Xiong (xiongyuj@mail.sysu.edu.cn) and Guo Yu Qiu (qiugy@pkusz.edu.cn)

Received: 5 May 2016 - Published in Hydrol. Earth Syst. Sci. Discuss.: 6 June 2016

Revised: 9 December 2016 - Accepted: 17 December 2016 - Published: 10 January 2017

\begin{abstract}
Water resources, which are considerably affected by land use/land cover (LULC) and climate changes, are a key limiting factor in highly vulnerable ecosystems in arid and semi-arid regions. The impacts of LULC and climate changes on water resources must be assessed in these areas. However, conflicting results regarding the effects of LULC and climate changes on runoff have been reported in relatively large basins, such as the Jinghe River basin (JRB), which is a typical catchment $\left(>45000 \mathrm{~km}^{2}\right)$ located in a semi-humid and arid transition zone on the central Loess Plateau, northwest China. In this study, we focused on quantifying both the combined and isolated impacts of LULC and climate changes on surface runoff. We hypothesized that under climatic warming and drying conditions, LULC changes, which are primarily caused by intensive human activities such as the Grain for Green Program, will considerably alter runoff in the JRB. The Soil and Water Assessment Tool (SWAT) was adopted to perform simulations. The simulated results indicated that although runoff increased very little between the 1970s and the 2000s due to the combined effects of LULC and climate changes, LULC and climate changes affected surface runoff differently in each decade, e.g., runoff increased with increased precipitation between the 1970s and the 1980s (precipitation contributed to $88 \%$ of the runoff increase). Thereafter, runoff decreased and was increasingly influenced by LULC changes, which contributed to $44 \%$ of the runoff changes between the 1980s and 1990s and $71 \%$
\end{abstract}

of the runoff changes between the 1990s and 2000s. Our findings revealed that large-scale LULC under the Grain for Green Program has had an important effect on the hydrological cycle since the late 1990s. Additionally, the conflicting findings regarding the effects of LULC and climate changes on runoff in relatively large basins are likely caused by uncertainties in hydrological simulations.

\section{Introduction}

Both climate and land use/land cover (LULC) changes are key factors that can modify flow regimes and water availability (Oki and Kanae, 2006; Piao et al., 2007; Sherwood and Fu, 2014; R. Wang et al., 2014). Since the 20th century, climate variability is believed to have led to changes in global precipitation patterns (IPCC, 2007), thereby changing the global water cycle and resulting in the temporal and spatial redistribution of water resources (Milly et al., 2005; Murray et al., 2012). LULC changes are primarily caused by human activities (Foley et al., 2005; Liu and Li, 2008) and affect the partitioning of water among various hydrological pathways, including interception, evapotranspiration, infiltration, and runoff (Sterling et al., 2012). The influences of climate and LULC changes on hydrological processes and water resources will likely continue to increase, especially in 
arid and semi-arid regions characterized as vulnerable $(\mathrm{Fu}$, 2003; Vorosmarty et al., 2010).

The impacts of LULC and climate changes on runoff can generally be identified by using hydrological models (Praskievicz and Chang, 2009). These models provide valuable frameworks for investigating the changes among various hydrological pathways that are caused by climate and human activities (Leavesley, 1994; Jiang et al., 2007; Wang et al., 2010). Distributed hydrological models, which use input parameters that directly represent land surface characteristics, have been applied to assess the impacts of LULC and climate changes on runoff in water resource management areas (Yang et al., 2008, 2014; Chen et al., 2016). The Soil and Water Assessment Tool (SWAT), a robust, interdisciplinary, and distributed river basin model, is commonly used to assess the effects of management practices and land disturbances on water quantity and quality (Gassman et al., 2007). The hydrological responses to LULC and climate changes are often investigated through scenario simulations using the SWAT model.

Although substantial progress has been made in assessing the impacts of LULC and climate changes on water resources (Krysanova and Arnold, 2008; Vigerstol and Aukema, 2011; Krysanova and White, 2015), most studies have focused on individual factors (i.e., either LULC or climate); thus, the combined effects of LULC and climate changes are not well understood because their contributions are difficult to separate and vary regionally (Fu et al., 2007; D'Agostino et al., 2010; R. Wang et al., 2014). For example, some studies have suggested that surface runoff is affected more by climate change (increased precipitation) than by LULC changes (Guo et al., 2008; Fan and Shibata, 2015), and other studies have found that urbanization contributes more to increased runoff than precipitation (Olivera and Defee, 2007). According to Krysanova and White (2015), less than 30 papers were published between 2005 and 2014 on topics related to the combined effects of LULC and climate changes and the SWAT model, whereas 210 and 109 papers presented studies of climate and LULC changes, respectively. However, water resource management requires an in-depth understanding of the isolated and integrated effects of LULC and climate changes on runoff (Chawla and Mujumdar, 2015).

Notable evidence of drying trends exists in semi-arid and semi-humid regions (Ma and Fu, 2006; Li et al., 2007, 2010, 2011). These regions have experienced serious water shortages in addition to intensive human activity and climate change (Wang and Cheng, 2000; $\mathrm{Ma}$ and $\mathrm{Fu}, 2003$ ). In this case, the effects of LULC and climate changes on runoff are considerably more sensitive, and a dry climate can result in serious environmental degradation and water crises (Ma et al., 2008; Jiang et al., 2011; Leng et al., 2016). The Jinghe River basin (JRB), which is located on the central Loess Plateau, is a typical catchment located in a semi-humid and semi-arid transition zone in northwest China. The agricultural activities in this basin play an important role in north- west China (Zhao et al., 2014). However, the relative importance of agriculture in the basin has caused ecological problems associated with social development. For example, local water resources cannot maintain the rapid socio-economic growth in the region (Wei et al., 2012), and the river system has become unhealthy (Wu et al., 2014). Water and environmental management in the region requires improved knowledge of the hydrological impacts of LULC and climate changes. The effects of LULC and climate changes on the water cycle and water resources must be assessed in these critical regions (Zhang et al., 2008; Li et al., 2009; Qiu et al., 2011, 2012; Peng et al., 2013).

Because the JRB transports the largest volume of sediment from the Loess Plateau to the Yellow River, hydrological studies of the basin have primarily assessed the impacts of soil and water conservation measures on surface runoff and sediment transport (e.g., Feng et al., 2012; He et al., 2015; Peng et al., 2015a, b; Wang et al., 2016). Relatively few studies have been conducted regarding the effects of LULC and climate changes on runoff. Studies of the Weihe River basin (Zuo et al., 2014) and Loess Plateau (Liang et al., 2015), which included the JRB as a sub-basin, have identified the response of runoff to climate change and human activities by using a climate elasticity model based on the Budyko framework. Zuo et al. (2014) found that runoff in the JRB decreased by $17.79 \mathrm{~mm}$ between 1997 and 2009, with human activities and climate change accounting for 51 and $39 \%$ of this decrease, respectively. Liang et al. (2015) showed that streamflow decreased substantially from 1961 to 2009, and the contribution of climate change $(65 \%)$ to streamflow reduction was much larger than that of ecological restoration measures (35\%) in the JRB. Another study based on the relationship between precipitation and runoff from 1966 to 1970 showed that runoff mainly decreased due to precipitation before the 2000s and due to human activity thereafter, which became dominant (with a contribution of greater than $76 \%$ ) (Zhang et al., 2011). The different results reported by Zuo et al. (2014) and Liang et al. (2015) suggest that assessing the impacts of LULC and climate changes on runoff in relatively large basins (over $1000 \mathrm{~km}^{2}$ ) is difficult (Chawla and Mujumdar, 2015; Peng et al., 2015b) due to their complex effects on streamflow (Fu et al., 2007) and the variable boundary conditions (Chen et al., 2011; Niraula et al., 2015).

Therefore, the objectives of this study were as follows: (1) to assess the surface runoff variability influenced by LULC and climate changes in recent decades in the JRB by using the SWAT model, which differs from the climate elasticity model based on the Budyko framework; (2) to quantify the combined and isolated impacts of LULC change and climate variability on surface runoff in the basin from 1971 to 2005 by using scenario simulations after calibrating and validating the SWAT model at monthly and yearly timescales; (3) to discuss how LULC and climate changes affect surface runoff; and (4) to discuss the simulation uncertainty in the context of SWAT modeling due to parameterizations and 
provide potential explanations for the conflicting results regarding the effects of LULC and climate changes on runoff in relatively large basins.

\section{Methods and materials}

\subsection{Study area}

The JRB, which covers an area of approximately $45421 \mathrm{~km}^{2}$, is located at $106^{\circ} 14^{\prime}-108^{\circ} 42^{\prime} \mathrm{E}$ and $34^{\circ} 46^{\prime}-37^{\circ} 19^{\prime} \mathrm{N}$ on the central Loess Plateau in northwest China (Fig. 1). The main stream of the Jinghe River, with a length of $450 \mathrm{~km}$, originates in the Liupan Mountains in the Ningxia Autonomous Region and flows across the Gansu and Shanxi provinces before draining into the Weihe River. The outlet gauging station, Zhangjiashan, has a control area of approximately $43216 \mathrm{~km}^{2}$. The study area is characterized by hills and syncline valleys, with the Liupan Mountains to the west and the Ziwu Mountains to the east. The elevation decreases from 2900 to $360 \mathrm{~m}$ above sea level. The climate varies from subhumid to semi-arid, with mean annual precipitation, temperature, and pan evaporation values of $390-560 \mathrm{~mm}, 8-13^{\circ} \mathrm{C}$, and $1000-1300 \mathrm{~mm}$, respectively. Precipitation mainly occurs between July and September, accounting for $50-70 \%$ of the total annual rainfall.

\subsection{Runoff change simulation}

Under the assumption that runoff is affected only by LULC and climate changes, the effects of LULC and climate changes on surface runoff were evaluated using SWAT. Before the simulations, the SWAT model was calibrated and validated as described below.

\subsubsection{SWAT model and data collection}

SWAT, a semi-distributed hydrological model, was developed to assess the impacts of land management and climate on water, nutrient, and pesticide transport at the basin scale (Arnold et al., 1998; Neitsch et al., 2005). SWAT simulates hydrological processes such as surface runoff at the daily timescale based on information regarding weather, topography, soil properties, vegetation, and land management practices. In SWAT, the study basin is divided into sub-basins, and each sub-basin is further subdivided into hydrological response units (HRUs) with homogeneous characteristics (e.g., topography, soil, and land use). Hydrological components are then calculated in the HRUs based on the water balance equation.

In this study, SWAT is operated via an interface in ArcView GIS (Di Luzio et al., 2002). Therefore, the required data are either raster or vector data sets, including a digital elevation model (DEM), soil properties, vegetation, LULC, meteorological observations, and discharge observations at Zhangjiashan gauging station.

\section{DEM}

The Shuttle Radar Topography Mission (SRTM) $90 \mathrm{~m}$ DEM (Jarvis et al., 2008) was used in this study.

2. Soil data

Soil property information was obtained from the soil map of China at a scale of $1: 1000000$. The map was provided by the Chinese Natural Resources Database. Loessial soils, which cover $75.10 \%$ of the basin area, is the major soil type in the area according to the Genetic Soil Classification of China. The other seven types are black loessial soils (13.27\%), neo-alluvial soils $(4.30 \%)$, grey cinnamon soils $(3.23 \%)$, cinnamon soils $(2.41 \%)$, red primitive soils $(1.10 \%)$, skeletal soils $(0.35 \%)$, and mountain meadow soils $(0.24 \%)$.

\section{Vegetation and LULC data}

LULC data from four periods were retrieved from Landsat images by supervised classification, i.e., Multispectral Scanner (MSS) images (60 $\mathrm{m}$ resolution) from 1979, Thematic Mapper (TM) images $(30 \mathrm{~m}$ resolution) from 1989, and Enhanced Thematic Mapper Plus (ETM+) images (30 m resolution) from 1999 and 2006. Each LULC data set represents the land use patterns for 1 decade (e.g., LULC data obtained from 1979 represents the land use patterns in the 1970s). Land use was classified into seven categories: forest, dense grassland, sparse grassland, cropland, water, barren areas, and urban and built-up areas. Then, the accuracy of the classification was verified, yielding a minimum Kappa coefficient of 0.73 (Xie et al., 2009).

\section{Meteorological data}

Daily precipitation was collected from 16 rainfall stations (Fig. 1), whereas the daily minimum and maximum temperatures, wind speed, and relative humidity data required by the SWAT model were collected from 12 meteorological stations between 1970 and 2005 . These data were interpolated to DEM grids using the SWAT model's built-in weather generator, which describes the weather conditions in the model simulations.

\section{Surface runoff}

Daily runoff data measured at the Zhangjiashan gauging station between 1970 and 1990 were collected from the State Hydrological Statistical Yearbook. These data were compared to the modeled surface flow during model calibration and validation.

\subsubsection{Model calibration and validation}

The SWAT model of the basin was first calibrated for the period of 1971 to 1997 and was then validated for the period of 1981 to 1990. Based on published results (e.g., Li et al., 2009) and our previous research results (Qiu et al., 2011), 


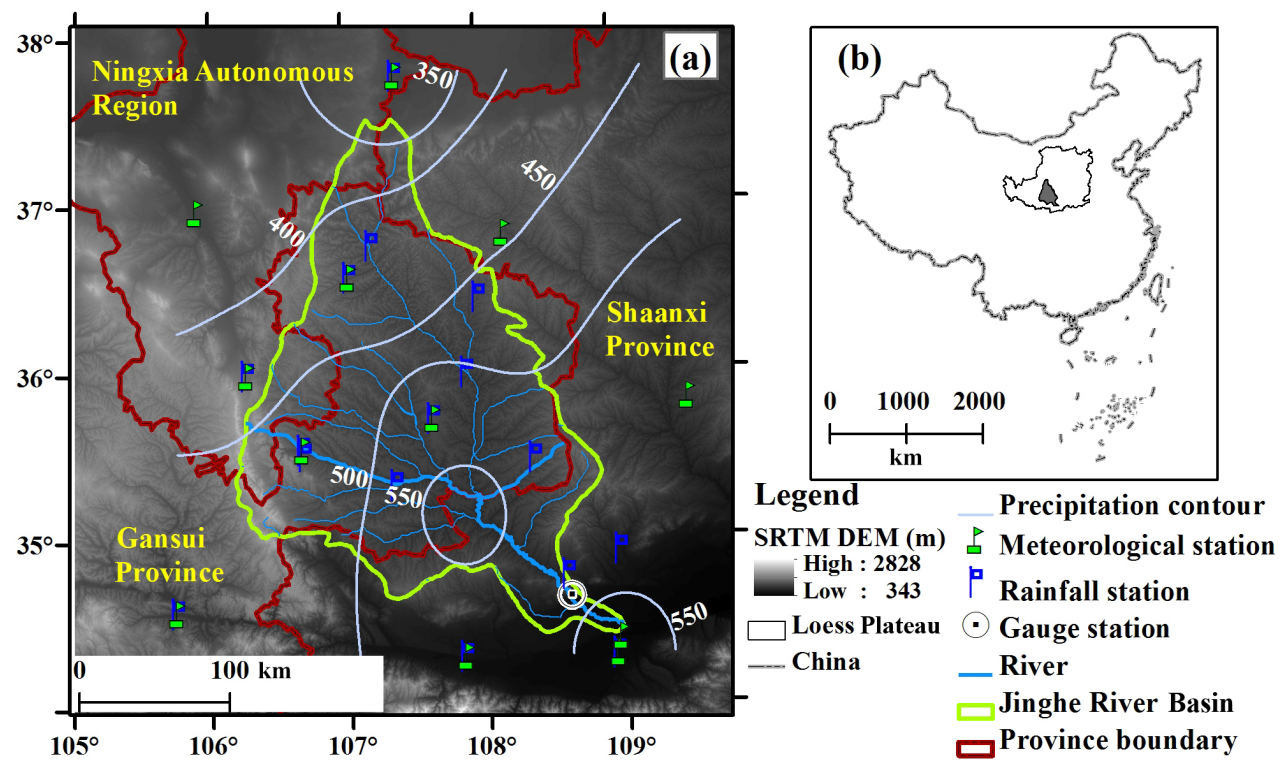

Figure 1. Geographic information regarding the study area: (a) location and SRTM DEM of the Jinghe River basin and (b) schematic of the selected study area in China. Precipitation (mm) is averaged and interpolated from meteorological data between 1970 and 2010.

the simulation was the most sensitive to the following six parameters: runoff curve number $\left(\mathrm{CN}_{2}\right)$, soil evaporation compensation factor (ESCO), the available water capacity of the soil layer (SOL_AWC), channel conductivity $\left(\mathrm{CH}_{-} \mathrm{K}_{2}\right)$, the baseflow alpha factor (ALPHA_BF), and the surface runoff coefficient (SURLAG). Therefore, these six parameters were calibrated in the SWAT model (Table 1) (Qiu et al., 2011). Model performance was assessed qualitatively using visual time series plots and quantitatively using the coefficient of determination $\left(R^{2}\right)$ and the Nash-Sutcliffe efficiency coefficient (Ens) (Eq. 1) (Moriasi et al., 2007):

Ens $=1-\frac{\sum_{i=1}^{n}\left(Q_{\mathrm{obs}}-Q_{\mathrm{sim}}\right)^{2}}{\sum_{i=1}^{n}\left(Q_{\mathrm{obs}}-Q_{\mathrm{obs}_{\mathrm{m}}}\right)^{2}}$,

where $Q_{\text {obs }}$ and $Q_{\text {sim }}$ are the observed and modeled runoff, respectively; $Q_{\mathrm{obs}_{\mathrm{m}}}$ is the mean value of observed runoff; and $n$ is the number of data records. When Ens approaches 1, the model simulates the measured data more accurately, whereas a negative Ens indicates that the model performance is poor. In this study, a criterion proposed by Moriasi et al. (2007), the Nash-Sutcliffe coefficient, was adopted to evaluate the simulation (Table 2).

The SWAT model was calibrated and validated based on annual and monthly river discharges measured at the outlet gauging station shown in Fig. 1.

\subsubsection{Simulation scenarios}

In this study, the effects of LULC and climate changes on surface runoff were evaluated by comparing the SWAT outputs of 10 scenarios. Each scenario represented 1 decade, and each simulation required an LULC map and a meteorological data set (Table 3). If the LULC map and the meteorological data were within the same decade (i.e., the 1970s, 1980s, 1990s, or 2000s), the simulation results represented "real runoff" or a "baseline" affected by the combination of LULC and climate changes. Alternatively, varying one driving factor while holding others constant simulated the effects of the variable factor on runoff ( $\mathrm{Li}$ et al., 2009). For example, to assess the response of streamflow to combined LULC and climate changes in the 1970s and 1980s, the simulation of the 1970s (1970-1979) ( $\left.Q_{\text {base }, i}\right)$, which is used as a reference period or baseline, should be based on the current LULC (year 1979) and current climate (years 19701979). The simulation of the 1980s (1980-1989) ( $\left.Q_{\text {base }, i+1}\right)$ should be based on future LULC (year 1989) and future climate (years 1980-1989). The difference between the first and second simulations represents the combined effects of LULC and climate changes on streamflow. Regarding LULC changes, the third simulation $\left(Q_{\text {sim,cL }, i}\right)$ was based on the current climate (years 1970-1979) and the LULC in the next period, or the future LULC (in this example, 1989). The difference between the first and third simulations is the effect of the LULC change on streamflow. Similarly, the difference between the first simulation and the fourth simulation ( $Q_{\text {sim,cc }, i}$ ) based on the current LULC (year 1979) and future climate (in this example, 1980-1989) represents the impact of climate change on streamflow. The combined effects 
Table 1. Calibrated values of the six parameters in SWAT.

\begin{tabular}{lllrr}
\hline No. & Parameter name & Description & $\begin{array}{r}\text { Range } \\
\begin{array}{r}\text { Calibrated } \\
\text { value }\end{array}\end{array}$ \\
\hline 1 & CN $_{2}$ & SCS runoff curve number for moisture condition II & -8 to +8 & -8 \\
2 & ESCO & Soil evaporation compensation factor & $0-1$ & 0.1 \\
3 & SOL_AWC & Available water capacity of the soil layer & $0-1$ & 0.05 \\
4 & CH_K & Channel conductivity & $0-150$ & 0.35 \\
5 & ALPHA_BF & Baseflow alpha factor & $0-1$ & 0.01 \\
6 & SURLAG & Surface runoff coefficient & $0-10$ & 0.85 \\
\hline
\end{tabular}

of LULC and climate changes on streamflow ( $\left.\Delta R_{\mathrm{comb}} \%\right)$ and the isolated effects of LULC $\left(\Delta R_{\text {iso,cL }} \%\right)$ and climate ( $\left.\Delta R_{\text {iso,cc }} \%\right)$ can be assessed using Eqs. (2) to (4):

$$
\begin{aligned}
& \Delta R_{\mathrm{comb}} \%=\left(\frac{Q_{\text {base }, i+1}-Q_{\text {base }, i}}{Q_{\text {base }, i}}\right) \times 100, \\
& \Delta R_{\mathrm{iso}, \mathrm{cL}} \%=\left(\frac{Q_{\text {sim }, \mathrm{cL}, i}-Q_{\text {base }, i}}{Q_{\text {base }, i}}\right) \times 100, \\
& \Delta R_{\text {iso,cc }} \%=\left(\frac{Q_{\text {sim }, \mathrm{cc}, i}-Q_{\text {base }, i}}{Q_{\text {base }, i}}\right) \times 100 .
\end{aligned}
$$

\section{Results}

\subsection{Climate change}

Variations in precipitation, dryness index $\left(E_{0} / P\right.$, defined as the ratio of annual potential evapotranspiration calculated using the Penman-Monteith method to annual precipitation), and air temperature were evaluated over 4 decades based on meteorological data from 1970 to 2009 (Fig. 2). Precipitation decreased by $3.4 \%$ from the 1970 s to the 2000 s. However, precipitation in the 1980 s was slightly higher than that in the 1970s. The decreasing trend in precipitation was substantial from the 1980 s to the 1990 s, reaching $4.1 \%$. Thereafter, the decrease in precipitation was less than that from 1980 to 1999. During the entire period (from the 1970 s to the $2000 \mathrm{~s}$ ), the temperature increased by $13.6 \%\left(1.18^{\circ} \mathrm{C}\right)$, including an abrupt increase of $0.7^{\circ} \mathrm{C}$ from the 1980 s to the $1990 \mathrm{~s}$. Although the dryness index exhibited little change (increasing by $1.8 \%$ ), a large dryness index $(>1.9)$ indicates that the climate became drier. These results indicate that the climate in the JRB changed dramatically over the last 4 decades, as characterized by decreased precipitation and increased temperature and dryness index values. Both warming and drying trends are evident in the JRB. These results agree with the results of other studies that reflect a broader phenomenon known as "climatic warming and drying" in northern China (Ma and Fu, 2003; Huang et al., 2012).

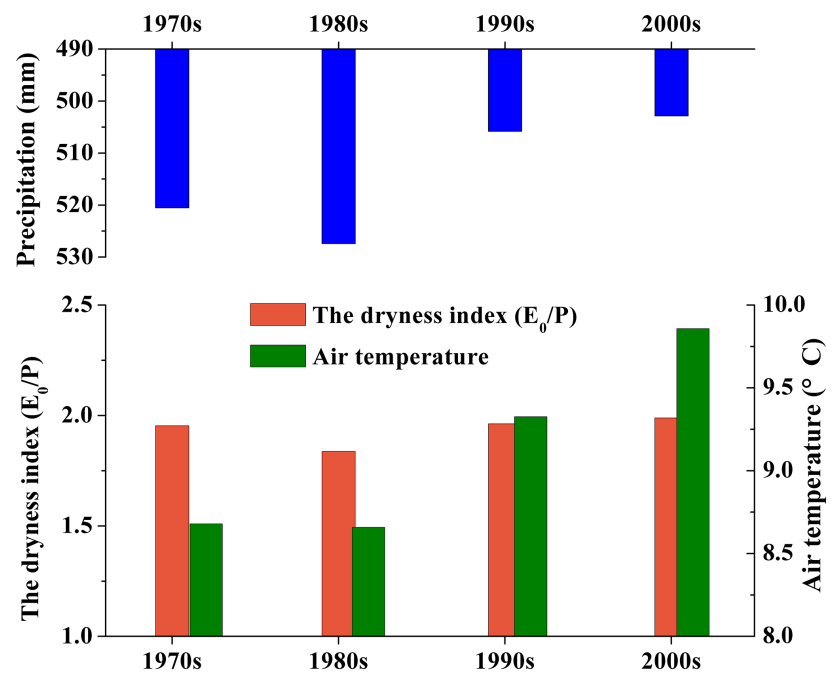

Figure 2. Variation in decadal mean precipitation (top), dryness index, and air temperature (bottom) in the Jinghe River basin from the 1970 s to the 2000s. The dryness index was defined as the ratio of annual potential evapotranspiration $\left(E_{0}\right)$ to annual precipitation $(P)$.

\subsection{LULC change}

Figure 3 shows the variations in LULC distributions over the last 4 decades. The dominant land use types are sparse grassland (with a vegetation coverage of $<20 \%$ ) and cropland, which encompass a total of $>61 \%$ of the area over the 4 decades. However, the percentage of sparse grassland was slightly higher than that of cropland, and the margin varied from 2.96 to $9.80 \%$. The remaining types include dense grassland (with a vegetation coverage of $\geq 20 \%$ ), forest, barren areas, urban and built-up areas, and water, with mean ratios of $17.57,13.71,6.35,0.31$, and $0.29 \%$, respectively. The vegetation with low coverage that is predominant in the study basin corresponds with the regional climate, and the relatively high percentage of cropland indicates the importance of agriculture in this area.

The statistical results illustrated by the four LULC maps over the last 4 decades indicate that vegetation (including grassland and forest) decreased by $11 \%$ between the $1970 \mathrm{~s}$ 


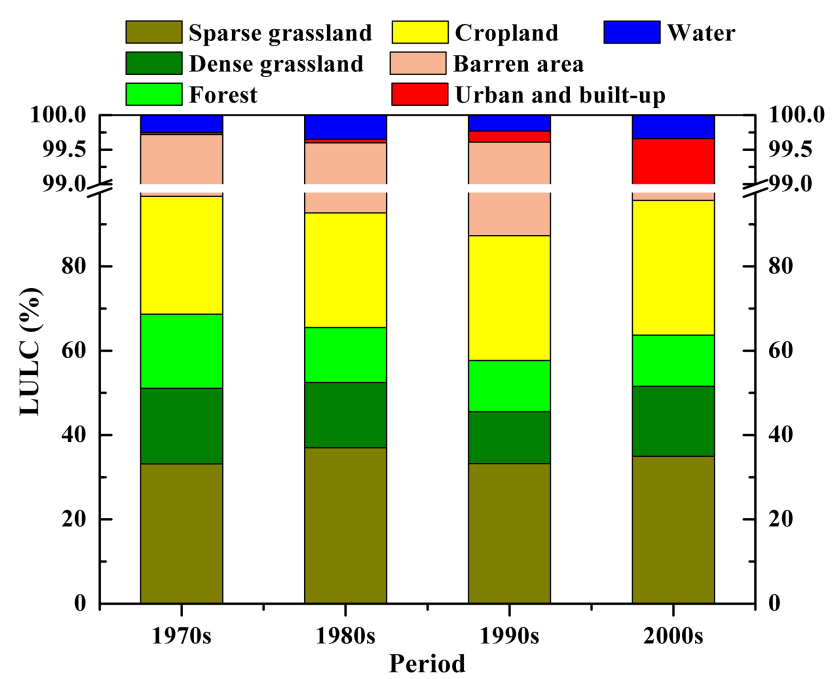

Figure 3. LULC composition and its change in the Jinghe River basin from the 1970 s to the 2000 s.

and the 1990s and increased by $6 \%$ thereafter. The areas of cropland and urban and built-up areas increased by 4.03 and $0.95 \%$, respectively, over time. The area of water fluctuated slightly, increasing by $0.09 \%$. The area of barren land increased from 3.09 to $12.35 \%$ before the 1990 s but then decreased to $3.02 \%$ in the 2000 s. The LULC changes potentially resulted from two major factors: social development and population growth. These factors have increased since the 1980s, leading to the expansion of urban and agricultural activities as well as unreasonable land utilization, reclamation of vulnerable land, and vegetation removal. Therefore, the areas of urban and barren land increased while the area of vegetation decreased. However, the decreasing trend in vegetation changed due to a nationwide environmental conservation programme initiated in 1999 by the Chinese government, the Grain for Green Program (GGP) (Xu et al., 2004). The main goal of the GGP was to reduce soil erosion and improve the eco-environmental status of western and northern China (Xu et al., 2004). Noticeable evidence of ecological restoration was observed on the Loess Plateau after the GGP was implemented (Chang et al., 2011; Sun et al., 2015). In addition to preventing soil erosion, the GGP improved the soil's physical and chemical properties (Deng et al., 2014; Song et al., 2014) and facilitated vegetation restoration. The results indicate that vegetation increased since the late 1990s, and these results agree with the results of other studies (e.g., Liang et al., 2015; Wang et al., 2016).

\subsection{Performance of the SWAT model}

The SWAT model performed well in both the calibration and validation periods, accurately simulating the outlet flows according to the model performance criteria ( $R^{2}$ and Ens) after the six sensitive parameters were optimized. During the
Table 2. SWAT performance of runoff simulations according to the Nash-Sutcliffe coefficient (Moriasi et al., 2007).

\begin{tabular}{ll}
\hline $\begin{array}{l}\text { Simulation } \\
\text { performance }\end{array}$ & $\begin{array}{l}\text { Nash-Sutcliffe coefficient } \\
(\text { Ens })\end{array}$ \\
\hline Very good & $0.75<$ Ens $\leq 1.00$ \\
Good & $0.65<$ Ens $\leq 0.75$ \\
Satisfactory & $0.50<$ Ens $\leq 0.65$ \\
Unsatisfactory & Ens $\leq 0.50$ \\
\hline
\end{tabular}

calibration period (1971-1980), the time series plots of simulations and observations were similar at both the annual (Fig. 4a) and monthly scales (Fig. 5a), although overestimation was observed in the simulated streamflow. Point-bypoint comparisons between the simulations and observations further showed that most of the paired streamflow values were distributed near the $1: 1$ line, with mean $R^{2}$ values of 0.90 (Fig. 4b) and 0.84 (Fig. 5b) at the annual and monthly scales, respectively (Qiu et al., 2011). In addition, the results of a statistical analysis indicated that the mean Ens values were 0.76 and 0.72 at the annual and monthly scales, respectively (Table 4). Similarly, although the SWAT model did not perform as well during the validation period (19811990) relative to the calibration period, the performance was still adequate, with Ens $\left(R^{2}\right)$ values of $0.73(0.83)$ and 0.69 $(0.77)$ at the annual and monthly scales, respectively (Table 4, Figs. 6 and 7).

Although the Ens performance statistic associated with SWAT runoff modeling can be larger than 0.8 in small or humid basins (e.g., Luo et al., 2008; Qiao et al., 2015; Wu et al., 2016), Ens is typically less than 0.7 in relatively large river basins in arid to semi-arid regions (e.g., Xu et al., 2011; Notter et al., 2013; Zhang et al., 2015; Liu et al., 2016; Zhao et al., 2016). The Ens values in this study were generally good in the calibration and validation periods and were comparable to those reported in other studies in arid to semi-arid river basins. The results suggested that the SWAT model performed well and was applicable to the study basin.

\subsection{Simulated surface runoff}

The annual runoff simulated by SWAT under different scenarios is shown in Table 3. Generally, runoff increased minimally between the 1970s and the 2000s at a rate of $1.51 \mathrm{~m}^{3} \mathrm{~s}^{-1}$ (simulations $\mathrm{S} 1$ and $\mathrm{S} 10$ ) due to the combined effects of LULC and climate changes (Fig. 8). However, runoff changed differently in different decades. For example, runoff increased by $35.4 \%\left(29.75 \mathrm{~m}^{3} \mathrm{~s}^{-1}\right)$ from the 1970 s to the 1980s (simulations S1 and S4) but decreased thereafter. Notably, the simulated runoff in the $1990 \mathrm{~s}$ was $12.59 \mathrm{~m}^{3} \mathrm{~s}^{-1}$ less than that in the 1980s (simulations S4 and S7), and runoff decreased by $15.5 \%\left(15.65 \mathrm{~m}^{3} \mathrm{~s}^{-1}\right)$ from the $1990 \mathrm{~s}$ to the 2000s (simulations S7 and S10) (Table 3). 
Table 3. Simulated annual runoff by SWAT under different scenarios considering both LULC and climate.

\begin{tabular}{lllrrrr}
\hline & \multicolumn{1}{c}{ Scenarios } & Climate & LULC & $\begin{array}{r}\text { Simulation } \\
\left(\mathrm{m}^{3} \mathrm{~s}^{-1}\right)\end{array}$ & $\begin{array}{r}\text { Runoff change } \\
\left(\mathrm{m}^{3} \mathrm{~s}^{-1}\right)\end{array}$ & $\begin{array}{r}\text { Runoff change } \\
(\%)\end{array}$ \\
\hline S1 & LULC and meteorological data from the 1970s & $1970 \mathrm{~s}$ & $1970 \mathrm{~s}$ & 84.10 & - & - \\
S2 & Changing LULC while holding climate constant & $1970 \mathrm{~s}$ & $1980 \mathrm{~s}$ & 86.40 & +2.30 & +7.73 \\
S3 & Changing climate while holding LULC constant & $1980 \mathrm{~s}$ & $1970 \mathrm{~s}$ & 110.17 & +26.07 & +87.63 \\
S4 & LULC and meteorological data from the 1980s & $1980 \mathrm{~s}$ & $1980 \mathrm{~s}$ & 113.85 & +29.75 & - \\
S5 & Changing LULC while holding climate constant & $1980 \mathrm{~s}$ & $1990 \mathrm{~s}$ & 107.02 & -6.83 & -54.25 \\
S6 & Changing climate while holding LULC constant & $1990 \mathrm{~s}$ & $1980 \mathrm{~s}$ & 108.61 & -7.04 & -55.92 \\
S7 & LULC and meteorological data from the 1990s & $1990 \mathrm{~s}$ & $1990 \mathrm{~s}$ & 101.26 & -12.59 & - \\
S8 & Changing LULC while holding climate constant & $1990 \mathrm{~s}$ & $2000 \mathrm{~s}$ & 90.20 & -11.06 & -70.67 \\
S9 & Changing climate while holding LULC constant & $2000 \mathrm{~s}$ & $1990 \mathrm{~s}$ & 94.67 & -6.59 & -42.11 \\
S10 & LULC and meteorological data from the 2000s & $2000 \mathrm{~s}$ & $2000 \mathrm{~s}$ & 85.61 & -15.65 & - \\
\hline
\end{tabular}
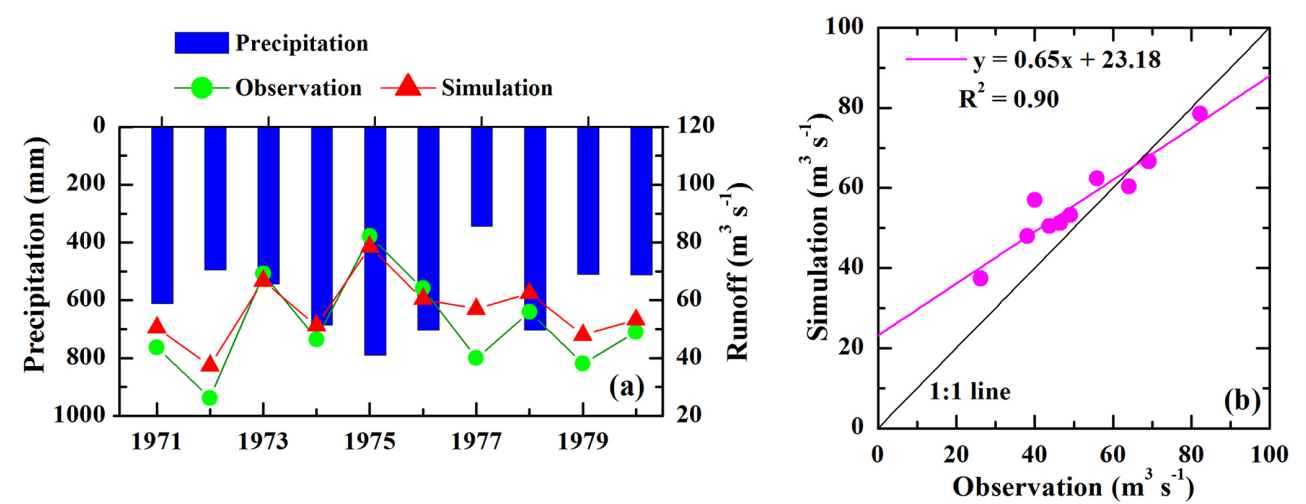

Figure 4. Comparison of observed and simulated runoff at the yearly scale in the Jinghe River basin during the calibration period from 1971 to 1980. Panel (b) is redrawn from Qiu et al. (2011).

Table 4. Nash-Sutcliffe coefficient (Ens) statistics in the SWAT calibration and validation periods.

\begin{tabular}{lll|ll}
\hline Statistic & \multicolumn{2}{c|}{$\begin{array}{c}\text { Calibration from } \\
1971 \text { to } 1980\end{array}$} & \multicolumn{2}{c}{$\begin{array}{c}\text { Validation from } \\
1981 \text { to } 1990\end{array}$} \\
\cline { 2 - 5 } & monthly & yearly & monthly & yearly \\
\hline$N$ & 120 & 10 & 120 & 10 \\
Minimum & 0.58 & 0.53 & 0.54 & 0.58 \\
Maximum & 0.95 & 0.98 & 0.81 & 0.9 \\
Mean & 0.72 & 0.76 & 0.69 & 0.73 \\
\hline
\end{tabular}

\section{Discussion}

\subsection{Impacts of LULC and climate changes on surface runoff}

The hydrological effects were analyzed using the simulated runoff data rather than the observed data. The combined effects of LULC and climate changes on surface runoff are presented in Sect. 3.4. The simulated runoff increased between the 1970s and the 1980s, while precipitation increased from 521 to $527 \mathrm{~mm}$ during the same period. Thereafter, runoff decreased as precipitation decreased. However, runoff decreased by $11.1 \%$ from the 1980 s to the 1990 s but decreased by $15.5 \%$ from the 1990 s to the 2000 s. These results indicate that, although precipitation can considerably affect runoff simulation, variations in runoff and precipitation were nonlinear due to the combined effects.

The isolated impacts of LULC and climate changes on surface runoff can be analyzed by comparing two sets of simulations. The differences between S1 and S2 (as well as between S4 and S5, and S7 and S8) reflect the impacts of climate change on runoff. Accordingly, the differences between $\mathrm{S} 1$ and S3 (as well as between S4 and S6, and S7 and S9) reflect the impacts of climate change on runoff.

\subsubsection{Isolated impacts of LULC change}

During the first 2 decades, LULC changes increased runoff by $2.30 \mathrm{~m}^{3} \mathrm{~s}^{-1}$ and accounted for $7.73 \%$ of the total change $\left(29.75 \mathrm{~m}^{3} \mathrm{~s}^{-1}\right)$. Thereafter, LULC change decreased runoff by $6.83 \mathrm{~m}^{3} \mathrm{~s}^{-1}$, which accounted for $54.25 \%$ of the total change in runoff $\left(12.59 \mathrm{~m}^{3} \mathrm{~s}^{-1}\right)$ from the $1980 \mathrm{~s}$ to the $1990 \mathrm{~s}$. The impacts of LULC changes on runoff increased during the last 2 decades because the contribution of LULC changes 

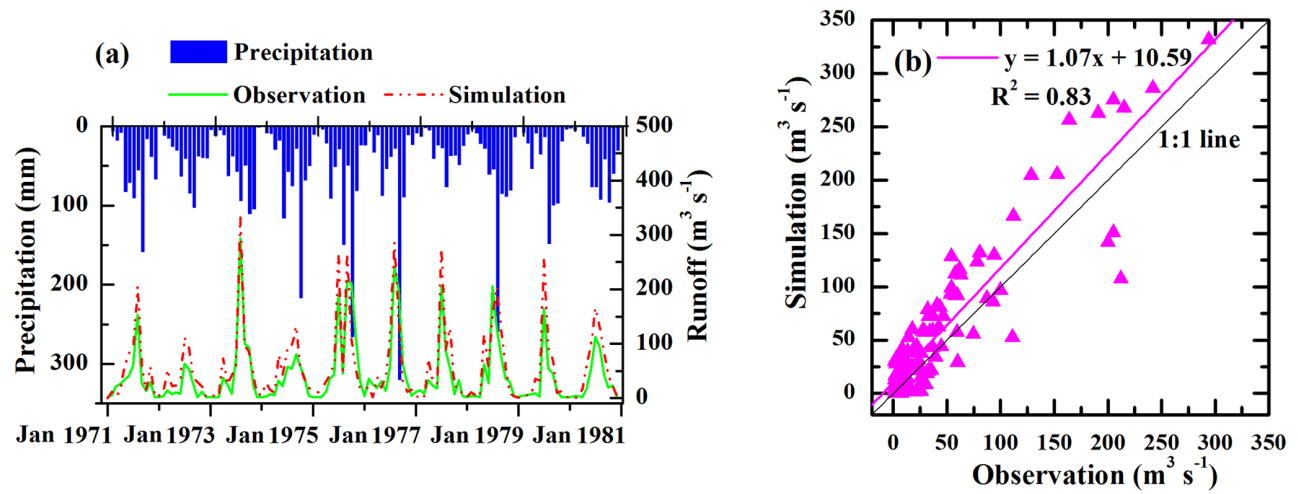

Figure 5. Comparison of observed and simulated runoff at the monthly scale in the Jinghe River basin during the calibration period from 1971 to 1980. Panel (b) is redrawn from Qiu et al. (2011).
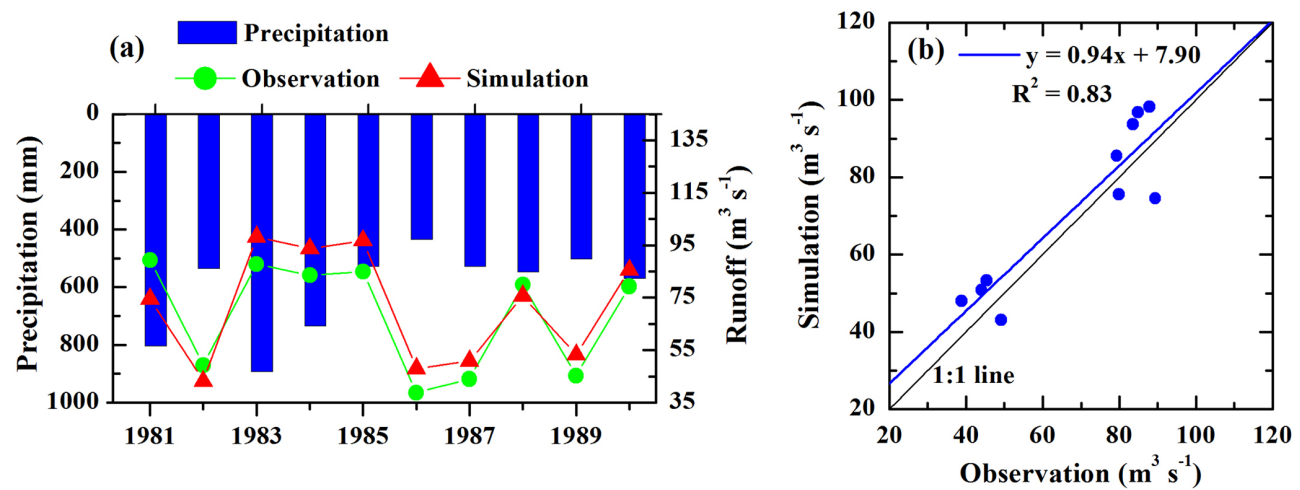

Figure 6. Comparison of observed and simulated runoff at the yearly scale in the Jinghe River basin during the validation from 1981 to 1990. Panel (b) is redrawn from Qiu et al. (2011).

to runoff increased to $70.67 \%$ from the 1990 s to the 2000 s (Fig. 9).

The results in Sect. 3.2 show that the LULC changed slightly from the 1970s to the 1980s. For example, the area of cropland marginally increased by $0.76 \%$, and the vegetative area decreased by $3.19 \%$. This small LULC change indicates that human activities minimally influenced runoff during the first 2 decades because the LULC changes only accounted for $7.73 \%$ of the increase in runoff. However, the LULC changed considerably with social development and population growth beginning in the 1980s. The vegetative area decreased by $7.81 \%$ from the 1980 s to the 1990 s, and the percentages of cropland, barren areas, and urban and builtup areas increased by $2.39,5.43$, and $0.11 \%$, respectively. LULC changes associated with increased human activities accounted for $54.25 \%$ of the increase in surface runoff. Furthermore, the GGP, which was initiated in the late 1990s, mitigated the decreasing trend in vegetation. Although cropland and urban and built-up areas still expanded by 2.40 and $0.82 \%$, respectively, from the 1990 s to the 2000 s, vegetation increased by $6.00 \%$, and barren areas decreased by $9.33 \%$. Therefore, LULC change exhibited a relatively large influ- ence on the surface runoff change, contributing to $70.67 \%$ of the surface runoff in the last 2 decades.

In addition, the spatial distributions of different land use types influence the generation of runoff. As reported in our previous publication (Qiu et al., 2011), the soil moisture content and evapotranspiration were modified by LULC changes (i.e., the GGP) in the JRB, which led to changes in surface runoff. However, the modification was different. Figure 10 shows that, after the GGP, the soil moisture content increased in the three selected sub-basins from the upstream to downstream regions, while the runoff and evapotranspiration decreased. When considering the upstream area as an example, barren land, with an initial percentage of $15.90 \%$, and partial farmland, with an initial percentage of $6.56 \%$, were converted to grassland due to the GGP, which improved water filtration and increased the soil moisture (Fig. 10a). The simulation in Fig. 10 shows that the soil moisture content increased by $163.66,208.23$, and $262.66 \%$ in the subbasins from the upstream to downstream, whereas the surface runoff (evapotranspiration) decreased by $-37.53,-38.55$, and $-49.01 \%(-1.21,-3.06$, and $-25.90 \%)$, respectively. These results indicate that the impacts of LULC changes on 
(a)
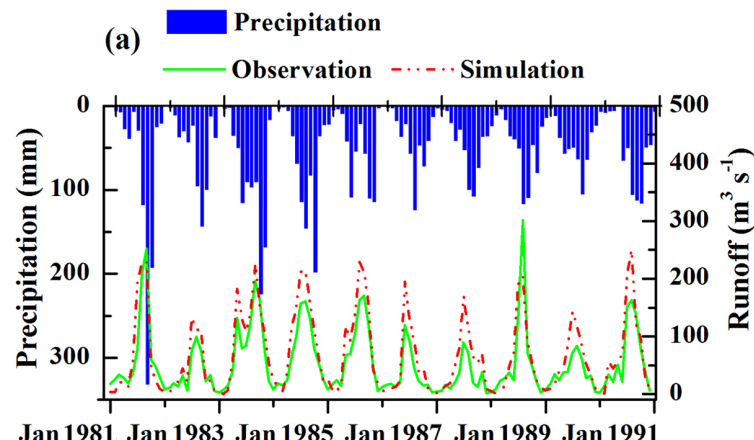

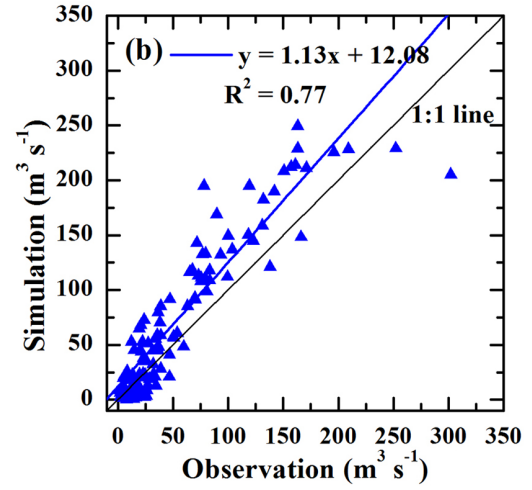

Figure 7. Comparison of observed and simulated runoff at the monthly scale in the Jinghe River basin during the validation period from 1981 to 1990. Panel (b) is redrawn from Qiu et al. (2011).

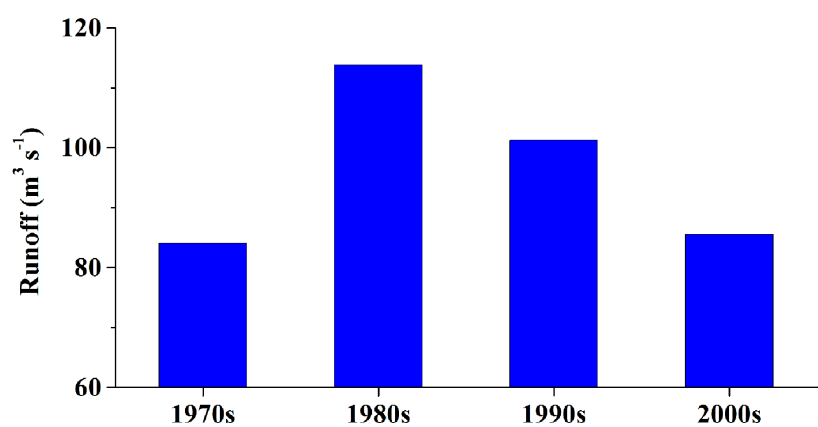

Figure 8. Variation in mean annual surface runoff at the decadal scale in the Jinghe River basin from the 1970s to the 2000s.

flow regimes were larger in the downstream areas of the basin than in the upstream areas.

Although climate variables were held constant when simulating LULC changes, the isolated influences of LULC changes on runoff did not exclude the impacts of precipitation variations because the climate (including precipitation) varied in each decade (Table 3). Nonetheless, the above results indicate that LULC changes contributed considerably to decreased runoff, as reported in previous studies (e.g., Zhang et al., 2011; Zuo et al., 2014; G. Wang et al., 2014; Wang et al., 2016). Additionally, the results suggest that vegetation restoration due to the GGP reduced surface runoff, which agrees with the results of other studies (e.g., Li et al., 2009; Nunes et al., 2011).

\subsubsection{Isolated impacts of climate change}

Unlike the contributions of LULC changes, the influences of climate change decreased in recent decades (Fig. 9). Climate change increased runoff by $26.07 \mathrm{~m}^{3} \mathrm{~s}^{-1}$ from the $1970 \mathrm{~s}$ to the 1980 s, accounting for approximately $87.63 \%$ of the increased total runoff during that period. Since the 1980s, surface runoff decreased, and the contributions of climate change to decreased runoff were 55.92 and $42.11 \%$ from the

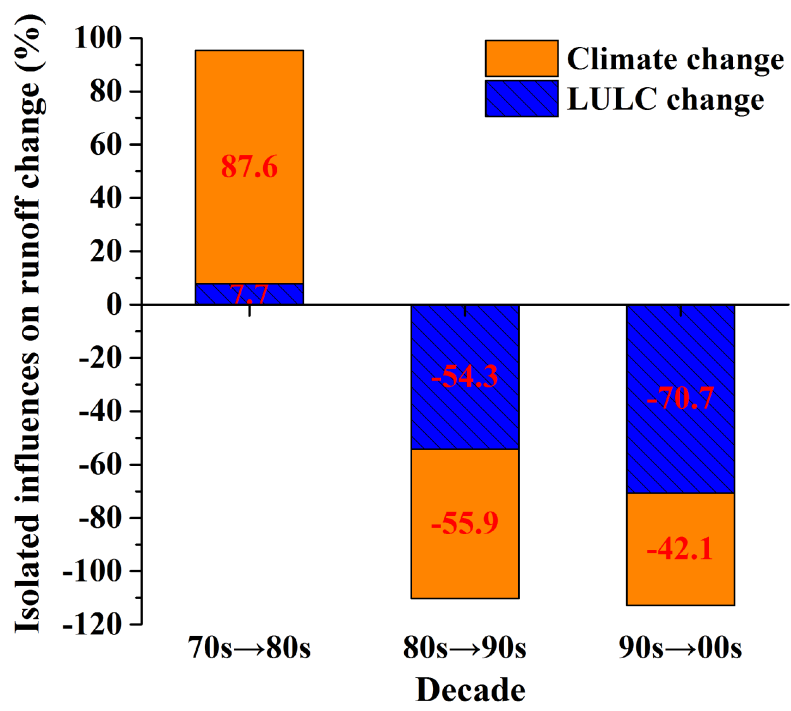

Figure 9. Isolated impacts of LULC and climate changes on surface runoff. Positive values indicate that runoff increased due to these factors, whereas negative values indicate that runoff decreased due to these factors. The summation of the isolated influences is not equal to $100 \%$ due to simulation uncertainty (see Sect. 4.2 for details).

1980 s to the 1990s and from the 1990s to the 2000s, respectively. The influence of climate change on runoff agrees with climatic warming and drying trends. Decreasing precipitation will potentially lead to less runoff, whereas increasing temperatures will result in increased evaporation.

In summary, LULC and climate changes accounted for 7.73 and $87.63 \%$ of the total runoff increase $\left(29.75 \mathrm{~m}^{3} \mathrm{~s}^{-1}\right)$ in the 1970s and 1980s, respectively. The isolated influences of LULC and climate changes on runoff were nearly the same from 1980 to 1999 (54.25 and 55.92\%, respectively) compared to the total decrease in runoff. In the last 2 decades, the percentage of the total runoff decrease that was caused 

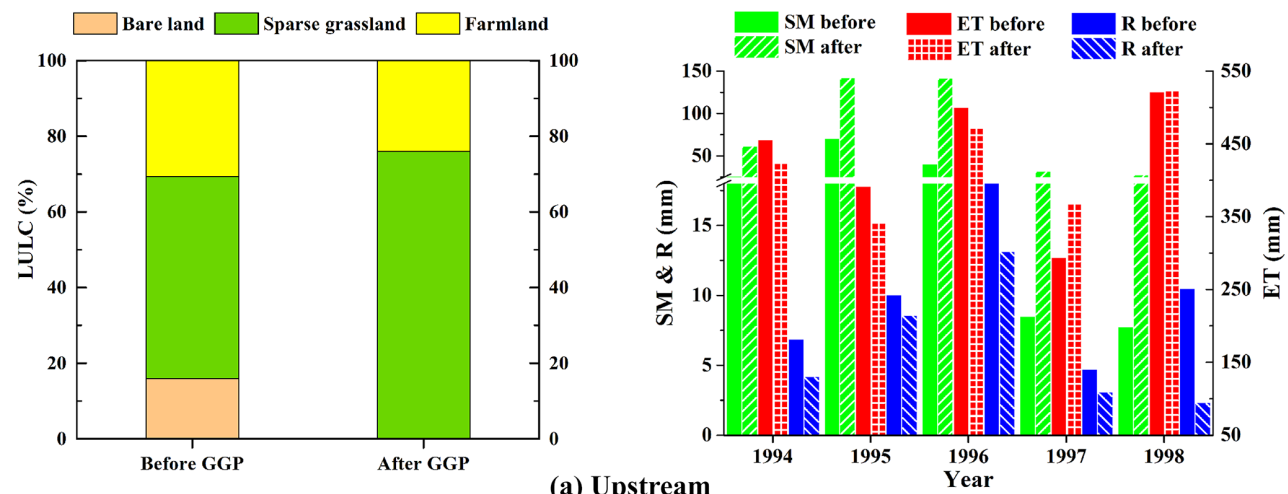

(a) Upstream
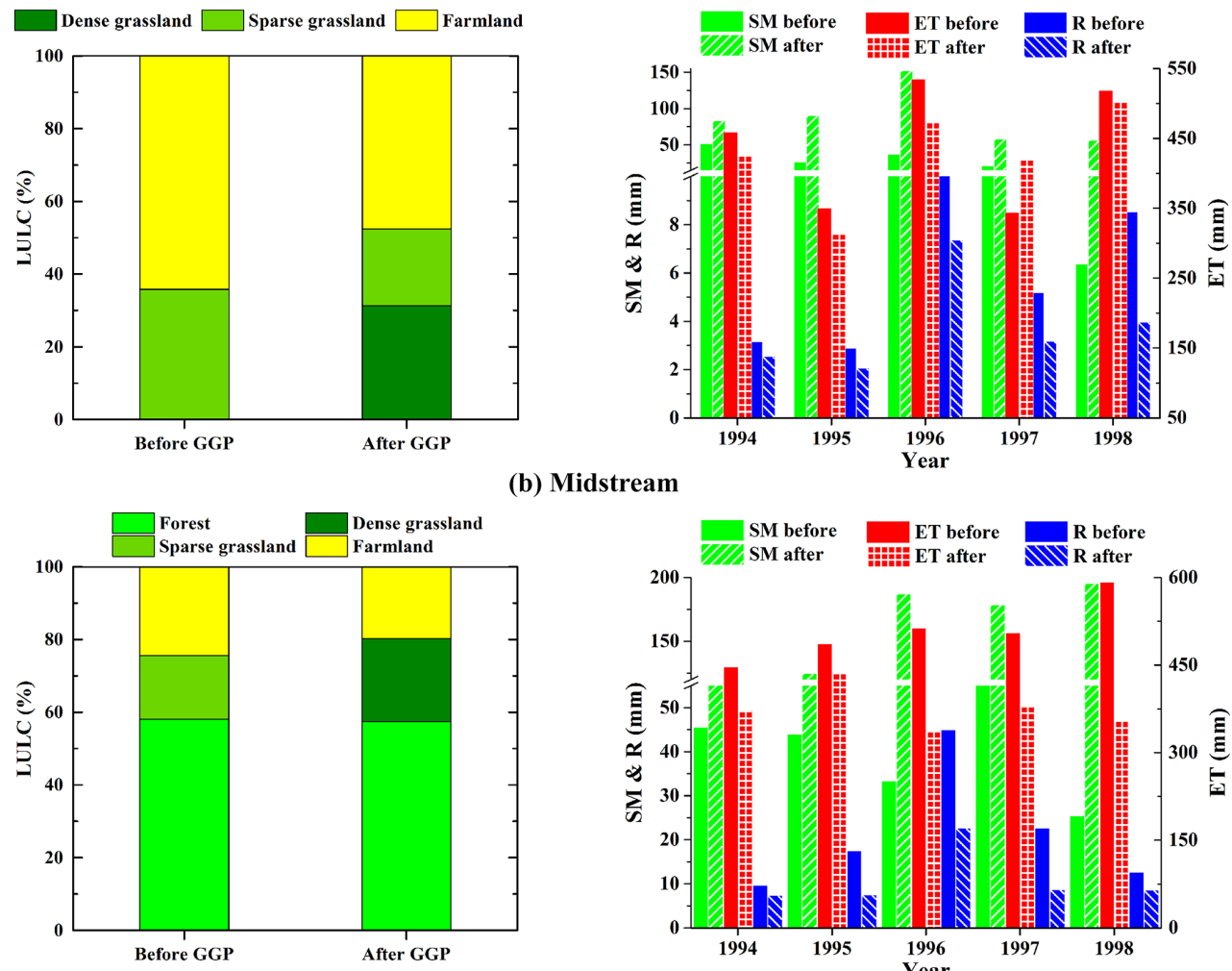

(b) Midstream

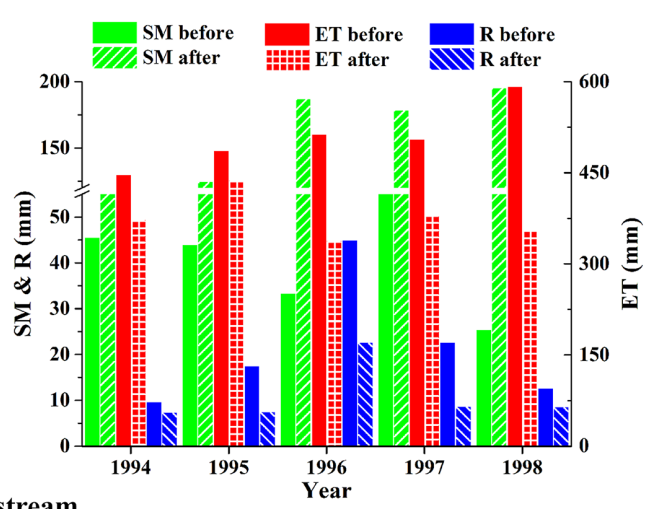

(c) Downstream

Figure 10. Impact of LULC changes on surface runoff in selected sub-basins distributed in the upstream, midstream, and downstream areas of the basin. The left column shows the land use types and corresponding ratios, and the right column shows the simulated changes of the soil moisture content (SM), evapotranspiration (ET), and surface runoff $(R)$ before and after the GGP scenarios while holding climate constant.

by LULC changes $(70.67 \%)$ was greater than that caused by climate change $(42.11 \%)$.

Although uncertainties exist in the simulations (see Sect. 4.2 for details), the above results indicate that the contribution of climate variability decreased over the last 4 decades, while the contribution of LULC change increased. Unlike the results reported by Liang et al. (2015), the findings in this study suggested that runoff fluctuations are influenced less by climate change and more by human activities. The results also indicate that the impacts of human activities on runoff have gradually increased in the JRB, which agrees with the results of other studies (Zhang et al., 2011; Zuo et al., 2014; Wang et al., 2016).

\subsection{Uncertainty in SWAT model simulations}

Uncertainty in model simulations, which is mainly caused by model structure (e.g., algorithm limitations) and model parameterizations, is a major challenge when assessing the impacts of LULC and climate changes on runoff in relatively large basins. In this study, the SWAT model performed well, with a Nash-Sutcliffe efficiency coefficient and coefficient of determination of 0.76 and 0.90 , respectively, for 
annual runoff during the calibration period, as well as values of 0.73 and 0.83 , respectively, during the validation period. However, under the assumption that runoff is affected only by LULC or climate changes, the simulated runoff associated with changes in only one driving factor was slightly different than the simulated runoff obtained when considering the combined effects of both factors due to the uncertainty in representing LULC and climate change interactions in the SWAT model. For example, $28.37 \mathrm{~m}^{3} \mathrm{~s}^{-1}$, which was the combined runoff rate in S2 and S3, was not equal to the "real or baseline runoff" of $29.75 \mathrm{~m}^{3} \mathrm{~s}^{-1}$ in S4.

Qiao et al. (2015) reported that the SWAT model performed much better in small watersheds ( $2-5 \mathrm{ha})$ than in a larger watershed $\left(78 \mathrm{~km}^{2}\right)$ because the meteorological inputs (e.g., precipitation) do not represent the spatial variability in a given parameter over larger basins because ground-based observations are limiting. To reduce the uncertainty and improve the accuracy of the hydrological model and forecasting results for relatively large basins, the uncertainty associated with model parameterization is discussed below and potential solutions are proposed for future studies.

In this study, the basin area exceeded $45000 \mathrm{~km}^{2}$. However, only 16 rainfall stations were available, among which 6 stations were outside the study basin. The station density was 0.35 stations per $1000 \mathrm{~km}^{2}$. Xu et al. (2013) found that model simulations are influenced by rainfall station densities below 0.4 per $1000 \mathrm{~km}^{2}$. Under such conditions, runoff simulations may contain uncertainties due to poor representation of spatial precipitation variability, which is crucial in determining the runoff hydrograph (Singh, 1997). Previous studies (e.g., Chu et al., 2012; Masih et al., 2011; Shope and Maharjan, 2015) have suggested that the density of rainfall measurement stations has a significant impact on SWAT simulations and that reducing the precipitation uncertainty can improve the accuracy of simulated streamflows. Although the SWAT model performed well in this study and the uncertainty in the simulations associated with precipitation was similar to the uncertainties observed in other studies, peak flow overestimation was observed in the simulated runoff (Figs. 4-7). To reduce uncertainty, precipitation from stations should be processed (e.g., via interpolation) before conducting runoff simulations, thereby improving the precision and spatial representativeness, especially in relatively large basins without reliable and precise areal rainfall data.

In addition, the coarse vegetation information provided by the LULC data in this study can lead to uncertainty in the simulations because vegetation distinction is required in SWAT modeling. Although the LULC data had a relatively high resolution of $30 \mathrm{~m}$, we can only provide a general vegetation categorization, such as forest, due to the data limitations. Recent results (e.g., Pierini et al., 2014; Qiao et al., 2015) have shown that detailed biophysical parameters of vegetation species can improve the performance of distributed, physically based models such as SWAT and reduce model uncertainty. In China, detailed and reliable data re- lated to vegetation species are uncommon. Reliable maps of vegetation species (as well as other geographic maps) at high spatial resolutions (e.g., $<1000 \mathrm{~m}$ ) are urgently needed to provide detailed and heterogeneous information for accurate biophysical and hydrological parameterization.

\section{Conclusions}

In this study, the SWAT model was used to simulate the effects of LULC and climate changes on surface runoff. The satisfactory performance of the SWAT model was confirmed by the Nash-Sutcliffe coefficient and coefficient of determination values of annual runoff of 0.76 and 0.90 , respectively, during the calibration period and 0.73 and 0.83 , respectively, during the validation period. Simulations showed that the combined effects of LULC and climate changes increased surface runoff by $29.75 \mathrm{~m}^{3} \mathrm{~s}^{-1}$ during the $1970 \mathrm{~s}$ and the 1980s, whereas LULC and climate changes both decreased runoff by $28.24 \mathrm{~m}^{3} \mathrm{~s}^{-1}$ during the $1980 \mathrm{~s}$ and the $2000 \mathrm{~s}$. Further analysis suggested that different driving factors had different influences on surface runoff.

The isolated results indicated that the impacts of LULC changes on the hydrological cycle were gradual, and that LULC changes altered runoff to a similar or greater extent than climate change, accounting for $70.67 \%$ of the streamflow reduction since the late 1990s. This result suggests that LULC plays an important role in the transition zone between semi-humid and semi-arid regions. As an indicator that is closely related to human activities, the LULC in the study area underwent considerable changes, especially the vegetation cover rate, which decreased by $16 \%$ from the 1970 s to the 1990s and increased by $6 \%$ between the 1990s and the 2000 s due to the GGP. In conclusion, the increased vegetation and land use changes inevitably altered the hydrological cycle, and large-scale LULC changes under the GGP considerably affected the hydrological cycle.

To reduce simulation uncertainty and improve the accuracy of hydrological modeling and forecasting in relatively large basins, areal input parameters (e.g., precipitation and vegetation species information) should be generated with reliable precision and high spatial resolution.

\section{Data availability}

The Shuttle Radar Topography Mission (SRTM) $90 \mathrm{~m}$ DEM is available at http://srtm.csi.cgiar.org/SELECTION/ inputCoord.asp. Meteorological data are available from the China Meteorological Administration website (http://data. $\mathrm{cma} . \mathrm{cn} / \mathrm{site} / \mathrm{index} . \mathrm{html}$ ) upon request. Other data used in this study are freely available for research purposes by contacting the authors. 
Acknowledgements. This study was supported by the National Natural Science Foundation of China (grant nos. 51309246 and 31300402), the China Scholarship Council (file no. 201606380186), and the National Basic Research Program of China (project no. 2006CB400505). We thank the China Meteorological Administration for providing meteorological data. We are grateful to the editors and reviewers for their insightful and constructive comments.

Edited by: Q. Chen

Reviewed by: two anonymous referees

\section{References}

Arnold, J. G., Srinivasan, R., Muttiah, R. S., and Williams, J. R.: Large area hydrologic modeling and assessment - Part 1: Model development, J. Am. Water Resour. As., 34, 73-89, 1998.

Chang, R. Y., Fu, B. J., Liu, G. H., and Liu, S. G.: Soil carbon sequestration potential for Grain for Green Project in Loess Plateau, China, Environ. Manage., 48, 1158-1172, 2011.

Chawla, I. and Mujumdar, P. P.: Isolating the impacts of land use and climate change on streamflow, Hydrol. Earth Syst. Sci., 19, 3633-3651, doi:10.5194/hess-19-3633-2015, 2015.

Chen, Y., Ren, Q. W., Huang, F. H., Xu, H. J., and Cluckie, I.: Liuxihe Model and its modeling to river basin flood, J. Hydrol. Eng., 16, 33-50, 2011.

Chen, Y., Li, J., and Xu, H.: Improving flood forecasting capability of physically based distributed hydrological models by parameter optimization, Hydrol. Earth Syst. Sci., 20, 375-392, doi:10.5194/hess-20-375-2016, 2016.

Chu, J., Zhang, C., Wang, Y., Zhou, H., and Shoemaker, C. A.: A watershed rainfall data recovery approach with application to distributed hydrological models, Hydrol. Process., 26, 1937-1948, 2012.

D’Agostino D. R., Trisorio, L. G., Lamaddalena, N., and Ragab, R.: Assessing the results of scenarios of climate and land use changes on the hydrology of an Italian catchment: modelling study, Hydrol. Process., 24, 2693-2704, 2010.

Deng, L., Liu, G. B., and Shangguan, Z. P.: Land use conversion and changing soil carbon stocks in China's "Grain-for-Green" Program: a synthesis, Glob. Change Biol., 20, 3544-3556, 2014.

Di Luzio, M., Srinivasan, R., Arnold, J. G., and Neitsch, S. L.: ArcView Interface for SWAT2000, User's Guide, Temple, Tex., Texas A\&M Agricultural Experiment Station, Blackland Research and Extension Center, 2002.

Fan, M. and Shibata, H.: Simulation of watershed hydrology and stream water quality under land use and climate change scenarios in Teshio River watershed, northern Japan, Ecol. Indic., 50, 7989, 2015.

Feng, X. M., Sun, G., Fu, B. J., Su, C. H., Liu, Y., and Lamparski, H.: Regional effects of vegetation restoration on water yield across the Loess Plateau, China, Hydrol. Earth Syst. Sci., 16, 2617-2628, doi:10.5194/hess-16-2617-2012, 2012.

Foley, J. A., DeFries, R., Asner, G. P., Barford, C., Bonan, G., Carpenter, S. R., Chapin, F. S., Coe, M. T., Daily, G. C., and Gibbs, H. K.: Global consequences of land use, Science, 309, 570-574, 2005.
Fu, C. B.: Potential impacts of human-induced land cover change on East Asia monsoon, Global Planet. Change, 37, 219-229, 2003.

Fu, G., Charles, S. P., and Chiew, F. H. S.: A two-parameter climate elasticity of streamflow index to assess climate change effects on annual streamflow, Water Resour. Res., 43, W11419, doi:10.1029/2007WR005890, 2007.

Gassman, P., Reyes, M. R., Green, C. H., and Arnold, J. G.: The soil and water assessment tool: Historical development, applications, and future research directions, T. ASABE, 50, 1211-1250, 2007.

Guo, H., Qi, H., and Jiang, T.: Annual and seasonal streamflow responses to climate and land-cover changes in the Poyang Lake basin, J. Hydrol., 355, 106-122, 2008.

He, Y., Wang, F., Mu, X. M., Yan, H. T., and Zhao, G. J.: An Assessment of Human versus Climatic Impacts on Jing River Basin, Loess Plateau, China, Advances in Meteorology, 2015, 478739, doi:10.1155/2015/478739, 2015.

Huang, J., Guan, X., and Ji, F.: Enhanced cold-season warming in semi-arid regions, Atmos. Chem. Phys., 12, 5391-5398, doi:10.5194/acp-12-5391-2012, 2012.

IPCC: Climate change 2007: the physical science basis, in: Contribution of working group I to the fourth assessment report of the intergovernmental panel on climate change, edited by: Solomon, S., Qin, D., Manning, M., Chen, Z., Marquis, M., Averyt, K. B., Tignor, M., and Miller, H. L., Cambridge University Press, Cambridge, UK, 2007.

Jarvis, A., Reuter, H. I., Nelson, A., and Guevara, E.: Holefilled SRTM for the globe Version 4, CGIAR-CSI SRTM $90 \mathrm{~m}$ Database, http://srtm.csi.cgiar.org (last access: 24 October 2015), 2008.

Jiang, S., Ren, L., Yong, B., Singh, V. P., Yang, X., and Yuan, F.: Quantifying the effects of climate variability and human activities on runoff from the Laohahe basin in northern China using three different methods, Hydrol. Process., 25, 2492-2505, 2011.

Jiang, T., Chen, Y. Q., Xu, C. Y., Chen, X. H., Chen, X., and Singh, V. P.: Comparison of hydrological impacts of climate change simulated by six hydrological models in the Dongjiang Basin, South China, J. Hydrol., 336, 316-333, 2007.

Krysanova, V. and Arnold, J. G.: Advances in ecohydrological modelling with SWAT - a review, Hydrolog. Sci. J., 53, 939-947, 2008.

Krysanova, V. and White, M.: Advances in water resources assessment with SWAT - an overview, Hydrolog. Sci. J., 60, 771-783, 2015.

Leavesley, G. H.: Modeling the effects of climate change on water resources: A review, Climate Change, 28, 159-177, 1994.

Leng, G., Tang, Q., Huang, S., Zhang, X., and Cao, J.: Assessments of joint hydrological extreme risks in a warming climate in China, Int. J. Climatol., 36, 1632-1642, 2016.

Li, J., Chen, F., Cook, E. R., Gou, X., and Zhang, Y.: Drought reconstruction for North Central China from tree rings: the value of the Palmer drought severity index, Int. J. Climatol., 27, 903-909, 2007.

Li, M. X., Ma, Z. G., and Niu, G. Y.: Modeling spatial and temporal variations in soil moisture in China, Chinese Sci. Bull., 56, 18091820, 2011.

Li, Z., Liu, W. Z., Zhang, X. C., and Zheng, F. L.: Impacts of land use change and climate variability on hydrology in an agricultural catchment on the loess plateau of China, J. Hydrol., 377, 35-42, 2009. 
Li, Z., Zheng, F. L., Liu, W. Z., and Flanagan, D. C.: Spatial distribution and temporal trends of extreme temperature and precipitation events on the Loess Plateau of China during 1961-2007, Quatern. Int., 226, 92-100, 2010.

Liang, W., Bai, D., Wang, F., Fu, B., Yan, J., Wang, S., Yang, Y., Long, D., and Feng, M.: Quantifying the impacts of climate change and ecological restoration on streamflow changes based on a Budyko hydrological model in China's Loess Plateau, Water Resour. Res., 51, 6500-6519, doi:10.1002/2014WR016589, 2015.

Liu, J., Liu, T., Bao, A. M., De Maeyer, P., Feng, X. W., Miller, S. N., and Chen, X.: Assessment of Different Modelling Studies on the Spatial Hydrological Processes in an Arid Alpine Catchment, Water Resour. Manag., 30, 1757-1770, 2016.

Liu, X. P. and Li, X.: Simulating complex urban development using kernel-based non-linear cellular automata, Ecol. Model., 211, 169-181, 2008.

Luo, Y., Zhang, X., Liu, X., Ficklin, D., and Zhang, M.: Dynamic modeling of organophosphate pesticide load in surface water in the northern San Joaquin Valley watershed of California, Environ. Pollut., 156, 1171-1181, 2008.

$\mathrm{Ma}, \mathrm{Z}$. and $\mathrm{Fu}, \mathrm{C}$. : Some evidence of drying trend over northern China from 1951 to 2004, Chinese Sci. Bull., 51, 2913-2925, 2006.

Ma, Z. G. and Fu, C. B.: Interannual characteristics of the surface hydrological variables over the arid and semi-arid areas of northern China, Global Planet. Change, 37, 189-200, 2003.

Ma, Z., Kang, S., Zhang, L., Tong, L., and Su, X.: Analysis of impacts of climate variability and human activity on streamflow for a river basin in arid region of northwest China, J. Hydrol., 352, 239-249, 2008.

Masih, I., Maskey, S., Uhlenbrook, S., and Smakhtin, V.: Assessing the Impact of Areal Precipitation Input on Streamflow Simulations Using the SWAT Model, J. Am. Water Resour. As., 47, 179-195, 2011.

Milly, P. C. D., Dunne, K. A., and Vecchia, A. V.: Global pattern of trends in streamflow and water availability in a changing climate, Nature, 438, 347-350, 2005.

Moriasi, D. N., Arnold, J. G., van Liew, M. W., Binger, R. L. Harmel, R. D., and Veith, T.: Model evaluation guidelines for systematic quantification of accuracy in watershed simulations, T. ASABE, 50, 885-900, 2007.

Murray, S. J., Foster, P. N., and Prentice, I. C.: Future global water resources with respect to climate change and water withdrawals as estimated by a dynamic global vegetation model, J. Hydrol., 448-449, 14-29, 2012.

Neitsch, S. L., Arnold, J. G., Kiniry, J. R., and Williams, J. R.: Soil and Water Assessment Tool Theoretical Documentation. Ver. 2005. Temple, Tex., USDA - ARS Grassland Soil and Water. Research Laboratory, and Texas A\&M University, Blackland Research and Extension Center, 2005.

Niraula, R., Meixner, T., and Norman, L. M.: Determining the importance of model calibration for forecasting absolute/relative changes in streamflow from LULC and climate changes, J. Hydrol., 522, 439-451, 2015.

Notter, B., Hans, H., Wiesmann, U., and Ngana, J. O.: Evaluating watershed service availability under future management and climate change scenarios in the Pangani Basin, Phys. Chem. Earth, 61-62, 1-11, 2013.
Nunes, A. N., de Almeida, A. C., and Coelho C. O. A.: Impacts of land use and cover type on runoff and soil erosion in a marginal area of Portugal, Appl. Geogr., 31, 687-699, 2011.

Oki, T. and Kanae, S.: Global hydrological cycles and world water resources, Science, 313, 1068-1072, 2006.

Olivera, F. and DeFee, B. B.: Urbanization and its effect on runoff in the Whiteoak Bayou watershed, Texas, J. Am. Water Resour. As., 43, 170-182, 2007.

Peng, H., Jia, Y. W., Qiu, Y. Q., and Niu, C. W.: Assessing climate change impacts on the ecohydrology of the Jinghe River basin in the Loess Plateau, China, Hydrolog. Sci. J., 58, 651-670, 2013.

Peng, H., Jia, Y., Tague, C., and Slaughter, P.: An Eco-Hydrological Model-Based Assessment of the Impacts of Soil and Water Conservation Management in the Jinghe River Basin, China, Water, 7, 6301-6320, 2015a.

Peng, H., Jia, Y., Niu, C. W., Gong, J. G., Hao, C. F., and Gou, S.: Eco-hydrological simulation of soil and water conservation in the Jinghe River Basin in the Loess Plateau, China, J. Hydroenvironment Research, 9, 452-464, 2015b.

Piao, S., Friedlingstein, P., Ciais, P., de Noblet-Ducoudré, N., Labat, D., and Zaehle, S.: Changes in climate and land use have a larger direct impact than rising $\mathrm{CO}_{2}$ on global river runoff trends, $\mathrm{P}$. Natl. Acad. Sci. USA, 104, 15242-15247, 2007.

Pierini, N., Vivoni, E., Robles-Morua, A., Scott, R., and Nearing, M.: Using observations and a distributed hydrologic model to explore runoff thresholds linked with mesquite encroachment in the Sonoran Desert, Water Resour. Res., 50, 8191-8215, 2014.

Praskievicz, S. and Chang, H.: A review of hydrological modeling of basin-scale climate change and urban development impacts, Prog. Phys. Geog., 33, 650-671, 2009.

Qiao, L., Zou, C., Will, R., and Stebler, E.: Calibration of SWAT model for woody plant encroachment using paired experimental watershed data, J. Hydrol., 523, 231-239, 2015.

Qiu, G. Y., Yin, J., Tian, F., and Geng, S.: Effects of the "Conversion of Cropland to Forest and Grassland Program" on the water budget of the Jinghe River Catchment in China, J. Environ. Qual., 40, 1-11, 2011.

Qiu, G. Y., Yin, J., and Geng, S.: Impact of climate and land-use changes on water security for agriculture in Northern China, Journal of Integrative Agriculture, 11, 144-150, 2012.

Sherwood, S. and Fu, Q.: A drier future, Science, 343, 737-739, 2014.

Shope, C. L. and Maharjan, G. R.: Modeling Spatiotemporal Precipitation: Effects of Density, Interpolation, and Land Use Distribution, Advances in Meteorology, 2015, 174196, doi:10.1155/2015/174196, 2015.

Singh, V. P.: Effect of spatial and temporal variability in rainfall and watershed characteristics on stream flow hydrograph, Hydrol. Process., 11, 1649-1669, 1997.

Song, X., Peng, C., Zhou, G., Jiang, H., and Wang, W.: Chinese Grain for Green Program led to highly increased soil organic carbon level: A meta-analysis, Scientific Reports, 4, 4460, doi:10.1038/srep04460, 2014.

Sterling, S. M., Ducharne, A., and Polcher, J.: The impact of global land-cover change on the terrestrial water cycle, Nature Climate Change, 3, 385-390, 2012.

Sun, W., Song, X., Mu, X., Gao, P., Wang, F., and Zhao, G.: Spatiotemporal vegetation cover variations associated with climate 
change and ecological restoration in the Loess Plateau, Agr. Forest Meteorol., 209-210, 87-99, 2015.

Vigerstol, K. and Aukema, J. E.: A comparison of tools for modeling freshwater ecosystem services, J. Environ. Manage., 92, 2403-2409, 2011.

Vorosmarty, C. J., McIntyre, P. B., Gessner, M. O., Dudgeon, D., Prusevich, A., Green, P., Glidden, S., Bunn, S. E., Sullivan, C. A., Reidy Liermann, C., and Davies, P. M.: Global threats to human water security and river biodiversity, Nature, 467, 555-561, 2010 .

Wang, G. and Cheng, G.: The characteristics of water resources and the changes of the hydrological process and environment in the arid zone of northwest China, Environ. Geol., 39, 783-790, 2000.

Wang, G., Yu, J., Shrestha, S., Ishidaira, K., and Takeuchi, H.: Application of a distributed erosion model for the assessment of spatial erosion patterns in the Lushi catchment, China, Environmental Earth Sciences, 61, 787-797, 2010.

Wang, G., Yang, H., Wang, L., Xu, Z., and Xue, B.: Using the SWAT model to assess impacts of land use changes on runoff generation in headwaters, Hydrol. Process., 28, 1032-1042, 2014.

Wang, R., Kalin, L., Kuang, W., and Tian, H.: Individual and combined effects of land use/cover and climate change on Wolf Bay watershed streamflow in southern Alabama, Hydrol. Process., 28, 5530-5546, 2014.

Wang, S., Fu, B. J., Piao, S. L., Lu, Y. H., Ciais, P., Feng, X. M., and Wang, Y. F.: Reduced sediment transport in the Yellow River due to anthropogenic changes, Nat. Geosci., 9, 38-41, 2016.

Wei, S., Yang, H., Song, J., Abbaspour, K. C., and Xu, Z.: System dynamics simulation model for assessing socio-economic impacts of different levels of environmental flow allocation in the Weihe River Basin, China, Eur. J. Oper. Res., 221, 248-262, 2012.

Wu, W., Xu, Z. X., Yin, X., W., and Zuo, D. P.: Assessment of ecosystem health based on fish assemblages in the Wei River basin, China, Environ. Monit. Assess., 186, 3701-3716, 2014.

Wu, Y. P., Liu, S. G., Yan, W. D., Xia, J. Z., Xiang, W. H., Wang, K. L., Luo, Q., Fu, W., and Yuan, W. P.: Climate change and consequences on the water cycle in the humid Xiangjiang River Basin, China, Stoch. Env. Res. Risk A., 30, 225-235, 2016.

Xie, F., Qiu, G. Y., Yin, J., Xiong, Y. J., and Wang, P.: Comparison of land use/land cover change in three sections of the Jinghe River basin between the 1970s and 2006, Journal of Natural Resources, 24, 1354-1365, 2009 (in Chinese with English abstract).
Xu, H., Taylor, R. G., and Xu, Y.: Quantifying uncertainty in the impacts of climate change on river discharge in sub-catchments of the Yangtze and Yellow River Basins, China, Hydrol. Earth Syst. Sci., 15, 333-344, doi:10.5194/hess-15-333-2011, 2011.

$\mathrm{Xu}, \mathrm{H} ., \mathrm{Xu}, \mathrm{C}$. Y., Chen, H., Zhang, Z., and Li, L.: Assessing the influence of rain gauge density and distribution on hydrological model performance in a humid region of China, J. Hydrol., 505, $1-12,2013$.

Xu, Z., Bennett, M. T., Tao, R., and Xu, J.: China's Sloping Land Conversion Programme four years on: current situation, pending issues, Int. Forest. Review, 6, 317-326, 2004.

Yang, H., Wang, G., Yang, Y., Xue, B., and Wu, B.: Assessment of the impacts of land use changes on nonpoint source pollution inputs upstream of the Three Gorges Reservoir, The Scientific World Journal, 2014, 526240, doi:10.1155/2014/526240, 2014.

Yang, J., Reichert, P., Abbaspour, K. C., Xia, J., and Yang, H.: Comparing uncertainty analysis techniques for a SWAT application to the Chaohe Basin in China, J. Hydrol., 358, 1-23, 2008.

Zhang, S. L., Wang, Y. H., Yu, P. T., Zhang, H. J., and Tu, X. W.: Impact of human activities on the spatial and temporal variation of runoff of Jinghe Basin, Northwest China, Journal of Arid Land Resource and Environment, 25, 66-72, 2011 (in Chinese with English abstract).

Zhang, X. P., Zhang, L., Zhao, J., Rustomji, P., and Hairsine, P.: Responses of streamflow to changes in climate and land use/cover in the Loess Plateau, China, Water Resour. Res., 44, W00A07.1W00A07.12, 2008.

Zhang, Y., Fu, G., Sun, B., Zhang, S., and Men B.: Simulation and classification of the impacts of projected climate change on flow regimes in the arid Hexi Corridor of Northwest China, J. Geophys. Res.-Atmos., 120, 7429-7453, 2015.

Zhao, A. Z., Zhu, X. F., Liu, X. F., Pan, Y. Z., and Zuo, D. P.: Impacts of land use change and climate variability on green and blue water resources in the Weihe River Basin of northwest China, CATENA, 137, 318-327, 2016.

Zhao, L., Lyu, A. F., Wu, J. J., Hayes, M., Tang, Z. H., He, B., Liu J. H., and Liu, M.: Impact of meteorological drought on streamflow drought in Jinghe River Basin of China, Chinese Geogr. Sci., 24, 694-705, doi:10.1007/s11769-014-0726-x, 2014.

Zuo, D. P., Xu, Z. X., Wu, W., Zhao, J., and Zhao, F. F.: Identification of Streamflow Response to Climate Change and Human Activities in the Wei River Basin, China, Water Resour. Manag., 28, 833-851, 2014. 